\title{
Evaluation of Pathogenic Bacteria Associated with Fresh Produce obtained from Selected Markets in Abeokuta
}

\author{
Afolabi O. R. ${ }^{7}$, Oloyede A.R. ${ }^{1,}$, Ibrahim T. A. ${ }^{2}$
}

(C) Uganda Martyrs University

\begin{abstract}
The bacterial quality of eight types of fresh produce obtained from selected markets in Abeokuta was determined. Two hundred forty (240) samples of fresh vegetables were examined for aerobic plate counts, coliform counts, and presence of Escherichia coli, toxigenic Staphylococcus aureus, Salmonella spp and Listeria spp. The aerobic plate counts ranged from $2.80 \log _{10} \mathrm{cfu} / \mathrm{g}$ to $15.60 \log _{10} \mathrm{cfu} / \mathrm{g}$ with the inner parts of cut- water melons having the highest value. Total coliform counts ranged from 0.0 to $11.80 \log _{10} \mathrm{cfu} / \mathrm{g}$. Pathogenic bacteria isolated were Escherichia coli, Staphylococcus aureus, Salmonella spp, Listeria spp, Shigella dysenteriae, Klebsiella pneumoniae, Enterobacter aerogenes, Bacillus spp, Pseudomonas aeruginosa and Streptococcus spp. These pathogens were mostly found at the outer leaves/ parts of the vegetables and render unsafe for human consumption. This study shows that the outer parts/ leaves of fresh produce are heavily contaminated with pathogenic bacteria and the fresh produce should be pre- treated thoroughly, so as to reduce the risk of food- borne outbreaks.
\end{abstract}

Keywords $\cdot$ Pathogenic bacteria $\cdot$ Bacterial quality $\cdot$ Coliform counts

\section{Introduction}

Fresh vegetables and fruits are essential parts of the diets of people all over the world. They play an important role in maintaining good health owing to the presence of mineral elements and vitamins which help to build bones and teeth, protect the body from diseases and regulate the body processes on which vitality and good health depend (Fayemi, 1999). In fact, nutritionists emphasize the importance of fruits and vegetables in a healthy diet and researchers have recommended the consumption of at least five servings of fruits and vegetables per day (Bari et al., 2002). Due to these recommendations, the level of consumption of fresh fruits and vegetables is continuously increasing. Nevertheless, a larger number of microbial infections associated with the consumption of fresh fruits and

\footnotetext{
${ }^{7}$ University of Agriculture. *Corresponding author: ck2432002@yahoo.co.uk.

${ }^{2}$ Rufus Giwa Polytechnic, Owo.
} 
vegetables have also been reported in recent years. These infections are caused by bacteria, parasites and viruses (Beuchat, 1996), which are transmitted through many types of fruits and vegetables. The produce is exposed to contamination at every step including cultivation, harvesting, transporting, packaging, storage and selling to the final consumers. Sources of pre and post harvest contamination include faeces, soil, irrigation water, improperly composted manure, air, wild and domestic animals, harvesting equipment, wash and rinse water, transport vehicles, improper storage, improper packaging, crosscontamination and improper human handling (Beuchat, 1996; Beuchat and Ryu, 1997; Afolabi and Oloyede, 2010).

In most cities in Nigeria, ready- to- eat vegetables and fruits are not subjected to processing before consumption. Some are used as ingredients in cooked dishes, but many are consumed raw without any treatment that would have destroyed pathogenic microorganisms present on them. Also, some fruits such as pawpaw, pineapple and water melon are peeled, cut into pieces, wrapped with transparent polythene bags and sold to the people. As consumers, there is need to recognise that food safety is important for fresh fruits and vegetables. Thus, there is need to determine the microbiological safety of these fresh produce.

The purpose of this study is to determine the level of pathogenic bacterial contamination of fresh fruits and vegetables sold in Abeokuta, Nigeria.

\section{Materials and Methods}

\section{Sample Collection}

In 2011, fresh vegetables and fruits such as cabbages, lettuces, cucumbers, onions, cutwater melons, garden eggs, tomatoes and carrots were randomly collected from three Local Government Areas of Ogun- State (Abeokuta South, Abeokuta North and Odeda), Nigeria. A total of 240 samples were collected and taken to the laboratory for analysis. For vegetables like cabbages and lettuces; the outer leaves, mid leaves and inner leaves were analysed. For onions; the outer bulbs and inner bulbs were analysed. For cucumbers, garden eggs, carrots and tomatoes; the outer parts and inner parts were analysed while the middle parts (whitish parts) and inner parts of cut- water melons were analysed. A total of 540 subsamples were analysed.

\section{Microbiological Analyses}

Approximately $5.0 \mathrm{~g}$ of each sample was chopped with $50.0 \mathrm{ml}$ of sterile peptone water (Biolab). Tenfold dilutions of homogenates were then made with sterile peptone water. Aerobic plate counts and total coliform counts were determined by plating in a standard Plate count agar (Oxoid) and MacConkey agar (Oxoid) plates in triplicates. The plates were incubated at $37^{\circ} \mathrm{C}$ for $48 \mathrm{~h}$. Colonies were counted on the plates and recorded. Pure cultures of bacterial isolates were obtained on the nutrient agar plates. Bacterial isolates were characterized on the basis of their cultural, morphological and biochemical properties and identified using Bergey's Manual of Determinative Bacteriology (Holt et al., 1994). Colonies on the MacConkey agar plates were picked and sub cultured using MacConkey agar. Colonies typical to gram negative coliforms were confirmed by examining them to determine if they were non-spore forming gram negative rods that produce gas from 
lactose and then subjected to Indole, Methyl red, Voges- proskaur and Citrate (IMVC) tests.

The prevalence of toxigenic Staphylococcus aureus in the samples was determined by inoculating nutrient broth supplemented with $7.5 \%$ Sodium chloride $(\mathrm{NaCl})$ with the diluents. The inoculated broth was incubated at $37^{\circ} \mathrm{C}$ for $24 \mathrm{~h}$. After $24 \mathrm{~h}$, a loopful of culture broth was streaked onto the plates of Mannitol salt agar (Oxoid) and incubated at $37^{\circ} \mathrm{C}$ for $48 \mathrm{~h}$. The pathogenic character of the organism was ascertained by coagulase test. The haemolysis activity of the organism was determined by streaking onto blood agar and incubated at $30^{\circ} \mathrm{C}$ for $24 \mathrm{~h}$.

Enrichment of Salmonella and Shigella species was performed using alkaline peptone water. The inoculated broth was incubated at $37^{\circ} \mathrm{C}$ for $24 \mathrm{~h}$. After $24 \mathrm{~h}$, a loopful of culture broth was streaked onto the plates of Salmonella - Shigella agar (oxoid) and Deoxycholate citrate agar (oxoid) and incubated at $37^{\circ} \mathrm{C}$ for $48 \mathrm{~h}$. Suspected colonies were subjected to series of biochemical tests.

For the detection of Listeria spp, $1.0 \mathrm{ml}$ of the diluents was spread over the plates of Blood agar and incubated at $37^{\circ} \mathrm{C}$ for $48 \mathrm{~h}$. Typical colonies were subjected to series of biochemical tests for identification.

\section{Statistical Analysis}

Aerobic plate counts and coliform counts were expressed as $\log _{10} \mathrm{cfu} / \mathrm{g} \pm$ S.D. Significant differences were established by Duncan Multiple Range test at 5\% level of significance.

\section{Results}

The aerobic plate counts (APC) and total coliform counts of fresh vegetables are shown in Table 1. The vegetables examined had an average APC values ranging from $2.80 \log _{10}$ $\mathrm{cfu} / \mathrm{g}$ to $15.60 \log _{10} \mathrm{cfu} / \mathrm{g}$. The inner parts of cut-water melons had the highest APC value while the inner leaves of cabbages had the lowest value. Heavy bacterial contamination ( $>5.0 \log _{10} \mathrm{cfu} / \mathrm{g}$ ) were observed at the outer leaves or outer parts of cucumbers, garden eggs, carrots and tomatoes; and inner parts of cut- water melons. In contrast, heavy bacterial contamination was found in both outer leaves and mid leaves of cabbages and lettuces as well as outer bulbs and inner bulbs of onions. Although, the inner leaves/ parts of the produce had lower APC values than other parts, except cut- water melons, but significant variability existed between the parts of the samples examined. No significant differences $(\mathrm{p}<0.05)$ in the APC values were attributable to produce type.

Total MacConkey agar counts (total coliform counts) of vegetable samples analysed ranged from 0.00 to $11.80 \log _{10} \mathrm{cfu} / \mathrm{g}$. The inner parts of cut- water melons were observed to contain highest number of coliform organisms. No coliform was found at the mid and inner leaves of cabbages, inner bulbs of onions and inner parts of cucumbers, carrots and tomatoes. In contrast, heavy coliforms were observed at the outer leaves or parts of cabbages, lettuces, onions, cucumbers, garden eggs, carrots and tomatoes as well as inner parts of cut- water melons (Table 1).

The incidence of Escherichia coli, toxigenic Staphylococcus aureus, Salmonella spp and Listeria spp in the produce is given in Table 2. A total of 240 samples (540 subsamples) were screened for the presence of these pathogens. Of these, 246, 245, 174 and 32 subsamples were found to contain E. coli, toxigenic S. aureus, Salmonella spp and Listeria spp respectively, representing about $45.60 \%, 45.40 \%, 32.20 \%$ and $5.92 \%$ incidence respectively. These pathogens were mostly found at the outer parts/ leaves of the 
produce while few were found at the inner parts/ leaves and this indicates that the outer leaves/ parts of fresh produce are highly contaminated with pathogenic bacteria and are not safe for human consumption. Other bacteria isolated from the vegetables examined were Klebsiella pneumoniae, Enterobacter aerogenes, Shigella dysenteriae, Pseudomonas aeruginosa, Bacillus spp and Streptococcus spp. (Table 3). All these bacteria are of public health significance and their presence in these produce indicates that the produce are highly contaminated.

\section{Discussion}

The occurrence of food-borne outbreaks associated with fresh produce has necessitated an examination of food safety measures during the growth and processing of these products. The present study indicates that the outer parts or leaves of many fresh vegetables and fruits, and inner parts of cut- water melon were adjudged as 'unsatisfactory' bacterial quality as APC values and total coliform counts of the samples were higher than the recommended standard for food $(<5 \log 10 \mathrm{cfu}$ of total bacterial counts per $\mathrm{g}$ of food sample and $<2 \log 10 \mathrm{cfu}$ of coliform per $\mathrm{g}$ of food sample). The quantitative results of this study support the previous findings of Thunberg et al., (2002) who detected high values of APC and total coliform counts in fresh produce collected from supermarkets and markets in metropolitan Washington D. C. Also, the outer parts or leaves of the vegetables and inner parts of cut- water melons were observed to be highly contaminated with Escherichia coli, toxigenic Staphylococcus aureus, Salmonella spp and Listeria spp and since $E$. coli is regarded as primary indicator for microbiological quality of food and water, this shows that these parts of the vegetables are not safe for human consumption.

Though, the inner parts or leaves of the vegetables are safe for human consumption, many people consume the whole vegetables i.e. both outer parts/ leaves and inner parts/ leaves and as such consume the contaminated vegetables and this may lead to occurrence of food borne diseases. In addition, the bacterial pathogens isolated from these vegetables were E. coli, Salmonella spp, Shigella dysenteriae, Klebsiella pneumonia, Staphylococcus aureus, Pseudomonas aeruginosa, Bacillus spp, Enterobacter aerogenes and Listeria spp. All these bacteria are of public health significance and their presence in food indicates that such food has been contaminated with faecal materials and it is unsafe for human consumption. These results corroborate previous findings of Kaneko et al., 1999; Johannessen et al., 2002; Joshi and Patel, 2005 and Afolabi et al., 2011. The sources of faecal contamination to these vegetables could be primarily from the irrigation water contaminated with faecal materials from abattoirs, pit latrine and human wastes (Afolabi and Oloyede, 2010a). Other sources of contamination are soil, improperly composted manure, washed or rinsed water, wild and domestic animals, air, human handling, harvesting equipment, transport vehicles, improper packaging and cross contamination (Beuchat, 1996; Beuchat and Ryu, 1997). In addition, the inner parts of cut- water melons may get contaminated from knives used for cutting, human handling, trays used during cutting, rinsed water and packaging materials as these products are cut, washed, wrapped with transparent nylon bags and sold to the consumers.

Previous study carried out by Afolabi and Oloyede (2010) showed that high concentration of Sodium chloride solution or chlorinated water removed most pathogens on the surfaces of fresh produce. It is therefore suggested that the outer surfaces of fresh vegetables and fruits to be consumed raw should be thoroughly washed with high 
concentration of sodium chloride or chlorinated water so as to remove the pathogens present on their surfaces. It is also suggested that the water melons consumers should desist from buying already cut water melons. They should buy whole water melon fruits, peel, cut and wash thoroughly before consumption. This will reduce the risk of food borne outbreaks.

\section{Conclusion}

In conclusion, the outer and mid parts or leaves of most fresh vegetables as well as inner parts of cut- water melons sold in Abeokuta are highly contaminated with food- borne pathogens. However, the quality of these vegetables can be improved through pretreatment of the fresh produce with anti-microbial agents such as chlorinated water and high concentration of sodium chloride solution, so as to decrease the density of microbial contamination from the surfaces of the fresh produce. The quality of fresh produce can also be improved by maintaining good hygienic conditions of the transport and storage facilities as well as proper handling, so that the risk of food- borne pathogens decreases and chances of food- borne outbreaks can be minimized.

\section{References}

Afolabi, O. R., Oloyede, A. R. (2010). Irrigation water as a possible source of food- borne pathogens in raw vegetables. International Journal of Agricultural Sciences, Science, Environment and Technology (ASSET). Series в. 9(2). (In press)

Afolabi, O. R., Oloyede, A. R. (2010). Effectiveness of chlorinated water, sodium hypochlorite, sodium chloride and sterile distilled water in killing pathogenic bacteria on fresh produce. Journal of Science and Sustainable Development. 3(1): 29- 35.

Afolabi. O. R., Oloyede, A. R., Agbaje, M. (2011). Bacterial quality and cytotoxicity screening of fresh vegetables irrigated with polluted waters. International Journal of Agricultural Sciences, Science, Environment and Technology (ASSET). Series в 10(1). (In press).

Bari, M.L., Inatsu, Y., Kawasaki, S., Nazuka, E., Isshiki, K. (2002). Calcinated calcium killing of Escherichia coli 0157:H7, Salmonella and Listeria monocytogenes on the surface of tomatoes. Journal of Food Protection. 65 (11):1706 - 1711.

Beuchat, L. R. (1996). Pathogenic microorganisms associated with fresh produce. Journal of Food Protection. 59(2): $204-216$.

Beuchat, L. R., Ryu, J. H. (1997). Produce handling and processing practices. Emerging Infectious Diseases. 3(4):459 - 465.

Fayemi, P. O. (1999). Nigerian Vegetables. Heinemann Educational Books Plc. Ibadan. Nigeria. 1- 7.

Holt, J. G., Krieg, N. R., Sneath, P. H. A., Staley, J. T., Williams, S. T. (1994). Bergey's Manual of Determinative Bacteriology, $9^{\text {th }}$ edition. Beltimore, M. D. Williams and Wilkins (eds).

Johannessen, G. S., Loncarevbic, S., Kruse, H. (2002). Bacteriological analysis of fresh produce in Norway. International Journal of Food Microbiology. 77(3): 199- 204.

Joshi, P. A., Patel, S. P. (2005). Microbiological analysis of fresh vegetables and fruits and effect of antimicrobial agents on microbial load. www.rediffmail.com. 1 -13.

Kaneko, K., Hayashidani, H., Ohtomo, Y., Kosuge, J., Kato, M., Yakahashi, K., Shiraki, Y., Ogawa, M. (1999). Bacterial contamination of ready- to- eat foods and fresh 
products in retail shops and food factories. Journal of Food Protection. 62(6): 644649.

Thunberg, R. L., Tran, T. T., Bennett, R. W., Matthews, R. N., Belay, N. (2002).

Microbial evaluation of selected fresh produce obtained at retail markets. Journal of

Food Protection. 65(4): 677- 682.

Table 1: Mean microbiological counts of selected fresh vegetables

\begin{tabular}{|c|c|c|c|c|}
\hline Vegetables & $\begin{array}{l}\text { Samples } \\
\text { analysed }\end{array}$ & $\begin{array}{l}\text { Regions } \\
\text { analysed }\end{array}$ & $\begin{array}{l}\text { Aerobic plate counts } \\
\left(\log _{10} \text { cfu/g } \pm S . D\right)\end{array}$ & $\begin{array}{l}\text { Total coliform counts } \\
\left(\log _{10} \mathrm{cfu} / \mathrm{g} \pm \mathrm{S} . \mathrm{D}\right)\end{array}$ \\
\hline \multirow[t]{3}{*}{ Cabbage } & \multirow[t]{3}{*}{30} & Outer leaves & $7.20 \pm 1.8^{\mathrm{a}}$ & $5.22 \pm 0.7^{a}$ \\
\hline & & Mid leaves & $6.52 \pm 3.0^{b}$ & $1.20 \pm 1.1^{\mathrm{c}}$ \\
\hline & & Inner leaves & $2.80 \pm 2.1^{c}$ & 0.00 \\
\hline \multirow[t]{3}{*}{ Lettuce } & \multirow[t]{3}{*}{30} & Outer leaves & $8.80 \pm 1.5^{\mathrm{a}}$ & $6.95 \pm 1.3^{\mathrm{a}}$ \\
\hline & & Mid leaves & $5.65 \pm 2.2^{b}$ & $3.40 \pm 0.02^{b}$ \\
\hline & & Inner leaves & $3.60 \pm 1.6^{c}$ & $1.60 \pm 0.60^{c}$ \\
\hline \multirow[t]{2}{*}{ Onion } & \multirow[t]{2}{*}{30} & Outer bulbs & $9.40 \pm 2.8^{\mathrm{a}}$ & $7.72 \pm 0.90^{\mathrm{a}}$ \\
\hline & & Inner bulbs & $5.80 \pm 1.8^{\mathrm{b}}$ & 0.00 \\
\hline \multirow[t]{2}{*}{ Cucumber } & \multirow[t]{2}{*}{30} & Outer parts & $9.80 \pm 1.2^{\mathrm{a}}$ & $6.44 \pm 1.8^{\mathrm{a}}$ \\
\hline & & Inner parts & $4.62 \pm 0.9^{c}$ & 0.00 \\
\hline \multirow[t]{2}{*}{ Garden eggs } & \multirow[t]{2}{*}{30} & Outer parts & $9.00 \pm 0.8^{\mathrm{a}}$ & $6.85 \pm 1.3^{a}$ \\
\hline & & Inner parts & $4.30 \pm 2.2^{c}$ & $2.10 \pm 0.5^{\mathrm{bc}}$ \\
\hline \multirow[t]{2}{*}{ Carrots } & \multirow[t]{2}{*}{30} & Outer parts & $10.60 \pm 0.8^{a}$ & $7.35 \pm 0.1^{a}$ \\
\hline & & Inner parts & $3.42 \pm 0.9^{c}$ & 0.00 \\
\hline \multirow[t]{2}{*}{ Tomatoes } & \multirow[t]{2}{*}{30} & Outer parts & $12.10 \pm 0.6^{d}$ & $9.80 \pm 1.6^{\mathrm{ad}}$ \\
\hline & & Inner parts & $4.20 \pm 1.1^{\mathrm{c}}$ & 0.00 \\
\hline \multirow[t]{2}{*}{ Cut- water melon } & \multirow[t]{2}{*}{30} & Mid parts & $3.12 \pm 0.08^{c}$ & $2.50 \pm 0.5^{\mathrm{bc}}$ \\
\hline & & Inner parts & $15.60 \pm 1.0^{\mathrm{d}}$ & $11.80 \pm 1.3^{\mathrm{d}}$ \\
\hline
\end{tabular}

Note: Means with different letters along the columns are significantly different $(\mathrm{P}<0.05)$

Table 2: Prevalence of Escherichia coli, toxigenic Staphylococcus aureus, Salmonella spp and Listeria spp in selected fresh vegetables

\begin{tabular}{|c|c|c|c|c|c|}
\hline Vegetables & $\begin{array}{l}\text { Regions } \\
\text { analysed }\end{array}$ & $\begin{array}{l}\text { Escherichia } \\
\text { coli/30 } \\
\text { samples }\end{array}$ & $\begin{array}{l}\text { Toxigenic } \\
\text { Staphylococcus } \\
\text { aureus/30 samples }\end{array}$ & $\begin{array}{l}\text { Salmonella } \\
\text { spp/30 } \\
\text { samples }\end{array}$ & $\begin{array}{l}\text { Listeria } \\
\text { spp/30 } \\
\text { samples }\end{array}$ \\
\hline \multirow{3}{*}{ Cabbage } & Outer leaves & 30 & 30 & 30 & 4 \\
\hline & Mid leaves & 0 & 2 & 0 & 0 \\
\hline & Inner leaves & 0 & 0 & 0 & 0 \\
\hline \multirow[t]{3}{*}{ Lettuce } & Outer leaves & 30 & 30 & 30 & 8 \\
\hline & Mid leaves & 6 & 4 & 4 & 0 \\
\hline & Inner leaves & 2 & 2 & 1 & 0 \\
\hline \multirow{2}{*}{ Onion } & Outer bulbs & 30 & 30 & 30 & 3 \\
\hline & Inner bulbs & 0 & 0 & 0 & 0 \\
\hline \multirow[t]{2}{*}{ Cucumber } & Outer parts & 30 & 30 & 28 & 4 \\
\hline & Inner parts & 0 & 0 & 0 & 0 \\
\hline \multirow[t]{2}{*}{ Garden eggs } & Outer parts & 27 & 24 & 6 & 4 \\
\hline & Inner parts & 0 & 0 & 0 & 0 \\
\hline \multirow[t]{2}{*}{ Carrots } & Outer parts & 30 & 30 & 14 & 2 \\
\hline & Inner parts & 0 & 0 & 0 & 0 \\
\hline \multirow[t]{2}{*}{ Tomatoes } & Outer parts & 30 & 30 & 18 & 5 \\
\hline & Inner parts & 0 & 0 & 0 & 0 \\
\hline \multirow[t]{2}{*}{ Cut- water melon } & Mid parts & 1 & 3 & 0 & 0 \\
\hline & Inner parts & 30 & 30 & 13 & 2 \\
\hline Total (\% incidence) & & $246(45.6 \%)$ & $245(45.4 \%)$ & 174 (32\%) & $32(5.92)$ \\
\hline
\end{tabular}


Table 3: Incidence of other pathogenic bacteria in selected fresh vegetables Cabbage Lettuce Onion Cucumber Garden Carrot Tomatoes egg water melon

\begin{tabular}{|c|c|c|c|c|c|c|c|c|}
\hline $\begin{array}{l}\text { Klebsiella } \\
\text { pneumoniae }\end{array}$ & + & + & + & + & + & + & + & + \\
\hline $\begin{array}{l}\text { Enterobacter } \\
\text { aerogenes }\end{array}$ & + & + & + & + & + & + & + & + \\
\hline $\begin{array}{l}\text { Shigella } \\
\text { dysenteriae }\end{array}$ & + & + & + & + & + & + & + & + \\
\hline $\begin{array}{l}\text { Pseudomonas } \\
\text { aeruginosa }\end{array}$ & + & + & - & + & - & - & + & + \\
\hline $\begin{array}{l}\text { Streptococcus } \\
\text { spp }\end{array}$ & + & + & + & + & - & - & + & + \\
\hline Bacillus spp & + & + & + & + & + & + & + & + \\
\hline
\end{tabular}

Note:

+: Presence

-: Absence 